\title{
An Improved Procedure for Protoplast Culture and Plant Regeneration of Spinach (Spinacia oleracea L.)
}

\author{
Takako Goto, Masanori Miyazaki and Masakazu Oku \\ Toyo Institute of Food Technology 4-23-2, Minami-hanayashiki, Kawanishi-shi, Hyogo 666
}

\begin{abstract}
Summary
Protoplasts of Spinacia oleracea $\mathrm{L}$. were cultured in a modified half-strength MS medium supplemented with KM8p vitamins, $1.0 \mathrm{mg} \cdot \mathrm{liter}^{-1} \mathrm{BA}, 1.0 \mathrm{mg} \cdot \mathrm{liter}^{-1} 2,4-\mathrm{D}$, and glucose or mannitol. Plating efficiency in the medium containing glucose as an osmoticum was much higher than that in the medium containing mannitol. The addition of KM8p organic acids to the glucose medium promoted the division of protoplasts slightly; the same addition to a medium containing mannitol appeared inhibitory to the cell division. Several shoots were formed from calli obtained on the MS medium containing $1.0-10.0 \mathrm{mg} \cdot \mathrm{liter}^{-1}$ IAA or IBA. Adventitious root was developed most vigorously on the MS medium containing $2 \%$ sucrose, $0.5 \mathrm{mg} \cdot \mathrm{liter}^{-1}$ IBA, and $0.8 \%$ agar when $\mathrm{pH}$ was adjusted to 6.3 . Some regenerated plantlets transferred to a greenhouse produced many seeds.
\end{abstract}

\section{Introduction}

Spinach, Spinacia oleracea L., belongs to Chenopodiaceae and is a very important vegetable, because it contains many vitamins and minerals, such as carotene, vitamin $\mathrm{C}$, calcium, and iron. However, spinach does not generally tolerate high temperatures and acid soil, and may contain a large amount of oxalate which interferes with $\mathrm{Ca}$ absorption if excessive amounts are ingested. Protoplast culture has become widely applied to studies on cell biology and molecular biology, because of its usefulness in genetic transformation, somatic hybridization, and induction of somaclonal variation.

We recently reported the first successful plant regeneration form mesophyll protoplasts of spinach (Goto and Miyazaki, 1992). However, efficiency of shoot regeneration was very low and only a few plantlets were obtained. Fujita et al. (1994) reported that callus formed from mesophyll protoplasts of spinach, but plantlets could not be regenerated from the protoplasts.

In the present study, we report a more efficient procedure for the protoplasts division and plant

Received 18 October 1995. Accepted 8 January 1996. regeneration from mesophyll protoplasts of spinach.

\section{Materials and Methods}

Mesophyll protoplasts of Spinacia oleracea L. cv. Jiromaru were isolated as described previously (Goto and Miyazaki, 1992).

Protoplasts $\left(1 \times 10^{5}\right.$ protoplasts $\left.\cdot \mathrm{ml}^{-1}\right)$ were cul. tured in $60 \times 15 \mathrm{~mm}$ plastic Petri dishes containing $3 \mathrm{ml}$ of liquid medium and the dishes were sealed with Parafilm (American National Can). The liquid medium contained a half-strength of MS inorganic salts (Murashige and Skoog, 1962), except $\mathrm{NH}_{4} \mathrm{NO}_{3}\left(200 \mathrm{mg} \cdot\right.$ liter $\left.^{-1}\right)$, KM8p vitamin (Kao and Michayluk, 1975), $1.0 \mathrm{mg} \cdot$ liter $^{-1}$ BA, 1.0 $\mathrm{mg} \cdot \mathrm{liter}^{-1} 2,4-\mathrm{D}$ and various combinations of glucose and mannitol with or without KM8p organic acids $\left(20 \mathrm{mg} \cdot\right.$ liter $^{-1}$ sodium pyruvate, 40 $\mathrm{mg} \cdot \mathrm{liter}^{-1}$ citric acid, $40 \mathrm{mg} \cdot \mathrm{liter}^{-1}$ malic acid and $40 \mathrm{mg} \cdot$ liter $^{-1}$ fumaric acid). The $\mathrm{pH}$ of the culture medium was adjusted to 5.8. The cultures were maintained at $25{ }^{\circ} \mathrm{C}$ in the dark for a week, and then placed under a 16 -hr photoperiod. The light $(2,000 \mathrm{~lx})$ was supplied by fluorescent lamps. Plating efficiency (PE) was defined as the percentage of dividing protoplasts after 10 days of culture against originally plated protoplasts. 
After a month of culture, protoplast-derived micro-colonies were transferred onto callus formation media. These media were composed of a half strength MS inorganic salts, KM $8 \mathrm{p}$ vitamins, 0.1 mg.liter ${ }^{-1} \mathrm{BA}, 1.0 \mathrm{mg} \cdot$ liter $^{-1} \mathrm{GA}_{3}, 2 \%$ sucrose, $0.25 \%$ gellan gum (Wako Pure Chemical Industries Ltd.) and various concentrations of auxin (IAA, IBA, NAA or 2,4-D). About one month later, the calli with a diameter of about $2 \mathrm{~mm}$ were transferred onto MS medium containing $2 \%$ sucrose, $0.25 \%$ gellan gum without plant growth regulators for shoot regeneration. All media for callus formation and shoot regeneration were adjusted to pH 5.8 .

Regenerated shoots were detached from the callus and transferred for rooting to test tubes containing MS media supplemented with various concentrations of IBA and sucrose, and $0.25 \%$ gellan gum or $0.8 \%$ agar (Wako Pure Chemical Industries Ltd.), and adjusted to three values of $\mathrm{pH}$. These test tubes were sealed with millipore films to prevent vitrification and maintained at $25{ }^{\circ} \mathrm{C}$ and a 10 -hr photoperiod.

Regenerated plantlets were transferred to indi. vidual pots containing vermiculite and covered with a small plastic bag to maintain high humidity for 1-2 weeks. Subsequently, the plants were grown in a greenhouse.

\section{Results}

Protoplasts began to divide after 4-5 days of culture. Plating efficiency of the medium containing glucose as an osmoticum/carbon source was much higher than that of the medium containing mannitol (Table 1). The highest plating efficiency
(9.9\%) was obtained from the medium containing $0.5 \mathrm{M}$ glucose.

In the medium containing both $\mathrm{KM} 8 \mathrm{p}$ organic acids and $0.5 \mathrm{M}$ mannitol, most of the protoplasts were damaged and no cell division was observed (Table 1, Fig. $1 \mathrm{~A}$ and $\mathrm{B}$ ). On the contrary, many protoplasts divided in the medium containing $0.5 \mathrm{M}$ glucose with or without KM8p organic acids, and formed a large number of micro-colonies (Fig. 1C and D). Protoplast division proceeded more rapidly in the medium containing KM8p organic acids.

Protoplast-derived micro-colonies developed more vigorously on the callus formation media containing $1.0-10.0 \mathrm{mg} \cdot$ liter $^{-1}$ IAA or 1.0-5.0 $\mathrm{mg} \cdot$ liter $^{-1}$ IBA one month after transfer (Table 2). Callus turned brown on the medium containing $10.0 \mathrm{mg} \cdot$ liter $^{-1}$ IAA or $5.0 \mathrm{mg} \cdot$ liter $^{-1}$ IBA. Com . pact and green calli were formed on the medium with $5.0 \mathrm{mg} \cdot$ liter $^{-1}$ IAA or $1.0 \mathrm{mg} \cdot$ liter $^{-1}$ IBA. About one month after transfer to shoot regeneration medium, green shoot primordia appeared and some of the calli formed embryos. Several shoots were regenerated from calli developed on the callus formation media containing 1.0-10.0 $\mathrm{mg} \cdot$ liter $^{-1}$ IAA or IBA. Calli derived from the media containing NAA or $2,4-\mathrm{D}$ did not regenerate shoots, whereas that containing $5.0 \mathrm{mg}^{\circ}$ liter $^{-1}$ 2,4-D did.

Adventitious roots were formed from the shoots excised from the calli about one month after transfer to a rooting medium. Among the three media with different $\mathrm{pH}$, adventitious roots were developed most vigorously on the medium adjusted to $\mathrm{pH} 6.3$ (Table 3). Adventitious root formation and development were hindered in the medium ad-

Table 1. Effect of sugars, sugar alcohol, and KM8p organic acids (KM8pOA) on the plating efficiency of spinach protoplasts.

\begin{tabular}{lc}
\hline Composition of medium & Plating efficiency \\
\hline $2 \%$ sucrose $+0.5 \mathrm{M}$ mannitol
\end{tabular}

Each value represents the mean $\pm \mathrm{SE}$ after 10 days of culture. 

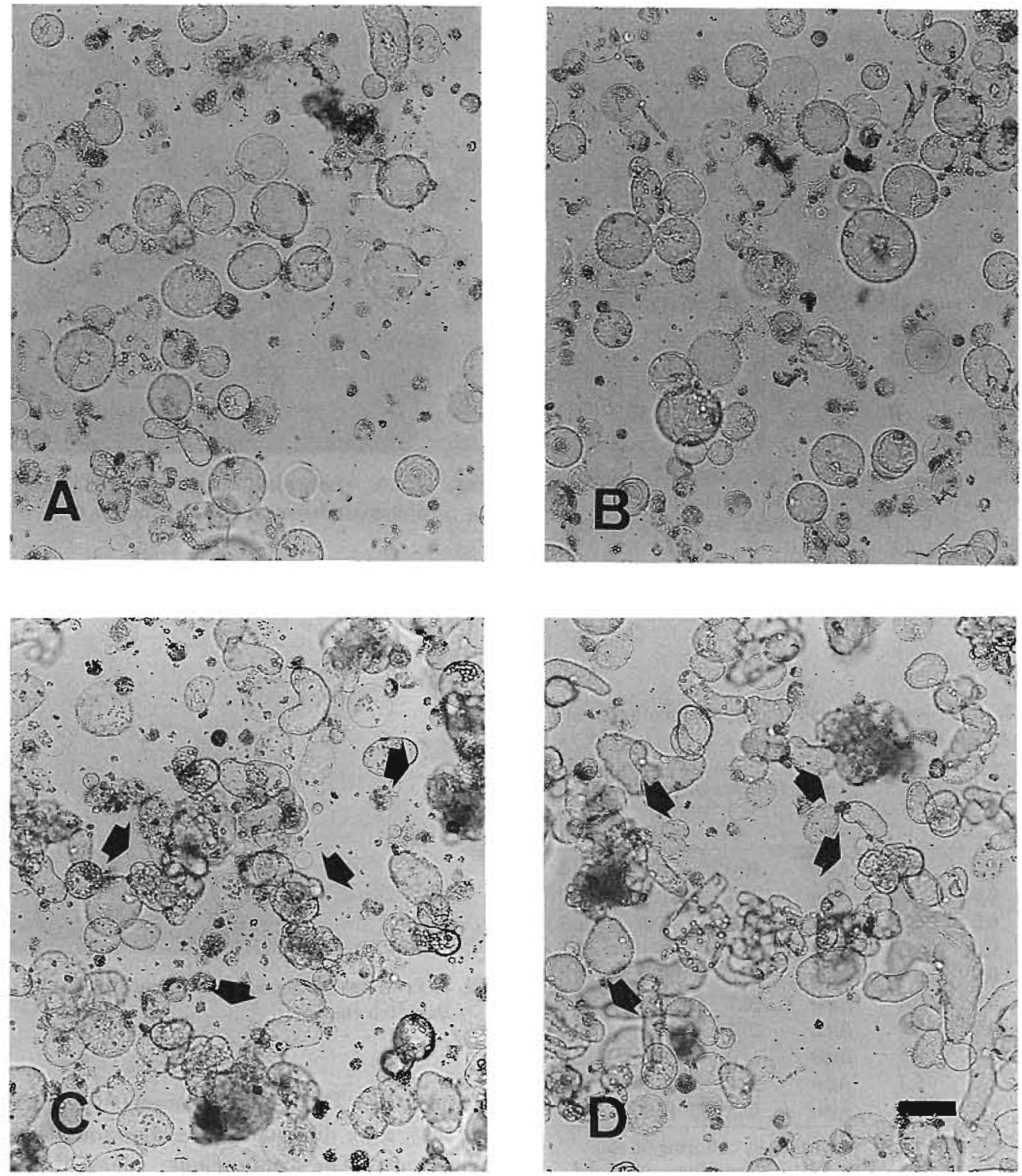

Fig. 1. Photomicrographs of protoplasts dividing on media containing mannitol and sugars in various combination with KM8p organic acids.

A : $0.5 \mathrm{M}$ mannitol and $2 \%$ sucrose. B : $0.5 \mathrm{M}$ mannitol and $2 \%$ glucose. $\mathrm{C}: 0.5 \mathrm{M}$ glucose. D : $0.5 \mathrm{M}$ glucose and $2 \%$ sucrose. Bar $=100 \mu \mathrm{m}$. Arrows indicate colonies.

justed to $\mathrm{pH} 6.8$.

On the medium containing agar as a gelling agent, numerous, large adventitious roots grew vigorously, more so than did the roots on the medium containing gellan gum. Adventitious root formation and their development were promoted by IBA; the maximum was attained in the medium containing $0.5 \mathrm{mg} \cdot 1$ iter ${ }^{-1}$ IBA.

The concentration of sucrose also affected the formation of adventitious roots. When the shoots were transplanted to the medium lacking sucrose, most did not produce adventitious roots but died. 
Table 2. Effect of auxin on callus formation medium on shoot regeneration after a month culture.

\begin{tabular}{|c|c|c|c|c|}
\hline \multicolumn{2}{|c|}{$\begin{array}{l}\text { Concn. of auxin } \\
\left(\mathrm{mg} \cdot \text { liter }^{-1}\right)\end{array}$} & \multirow{2}{*}{$\begin{array}{c}\begin{array}{c}\text { No. of calli } \\
\text { transplanted }\end{array} \\
22\end{array}$} & \multirow{2}{*}{$\begin{array}{c}\begin{array}{c}\text { No. of calli } \\
\text { forming shoot }\end{array} \\
1\end{array}$} & \multirow{2}{*}{$\begin{array}{l}\text { Shoot formation } \\
\text { ratio }(\%) \\
4.5\end{array}$} \\
\hline IAA & 1 & & & \\
\hline IAA & 5 & 36 & 5 & 13.4 \\
\hline IAA & 10 & 28 & 3 & 10.7 \\
\hline IBA & 1 & 31 & 3 & 9.7 \\
\hline IBA & 5 & 30 & 2 & 6.7 \\
\hline IBA & 10 & 8 & 1 & 12.5 \\
\hline NAA & 1 & 13 & 0 & 0 \\
\hline $\mathrm{NAA}$ & 5 & 19 & 0 & 0 \\
\hline NAA & 10 & 13 & 0 & 0 \\
\hline $2,4-D$ & 1 & 24 & 0 & 0 \\
\hline $2,4-D$ & 5 & 6 & 1 & 16.7 \\
\hline $2,4-D$ & & 12 & 0 & 0 \\
\hline
\end{tabular}

$z$ Colonies were cultured on $1 / 2 \mathrm{MS}$ medium contained KM8p vitamins, $0.1 \mathrm{mg} \cdot$ liter $^{-1} \mathrm{BA}, 1.0 \mathrm{mg} \cdot \mathrm{liter}^{-1} \mathrm{GA}_{3}$, $2.0 \%$ sucrose, $0.25 \%$ gellan gum,and several kinds and concentrations of auxins.

$y \quad$ Calli developed more than $2 \mathrm{~mm}$ in diameter were transplanted to MS medium containing $2.0 \%$ sucrose, $0.25 \%$ gellan gum.

Table 3. Frequency of adventitious root formation from shoots derived from protoplasts.?

\begin{tabular}{|c|c|c|c|c|c|c|}
\hline \multirow{2}{*}{\multicolumn{2}{|c|}{$\begin{array}{l}\text { IBA Sucrose } \\
\left(\mathrm{mg} \cdot \mathrm{liter}^{-1}\right)(\%)\end{array}$}} & \multirow[t]{2}{*}{$\mathrm{pH}$} & \multirow{2}{*}{$\begin{array}{l}\text { Gelling } \\
\text { agent }\end{array}$} & \multicolumn{3}{|c|}{ Adventitious root (\%) ${ }^{\%}$} \\
\hline & & & & $<2 \mathrm{~cm}$ & $\geqq 2 \mathrm{~cm}$ & total \\
\hline 0.5 & 0.5 & 5.8 & Agar & 40.0 & 6.7 & 46.7 \\
\hline 0.5 & 0.5 & 6.3 & Agar & 26.7 & 20.0 & 46.7 \\
\hline 0.5 & 0.5 & 6.8 & Agar & 26.7 & 0 & 26.7 \\
\hline 0.5 & 0.5 & 6.3 & Gellan gum & 26.7 & 0 & 26.7 \\
\hline 0 & 0.5 & 6.3 & Agar & 20.0 & 13.3 & 33.3 \\
\hline 0.1 & 0.5 & 6.3 & Agar & 26.7 & 6.7 & 33.3 \\
\hline 1.0 & 0.5 & 6.3 & Agar & 26.7 & 13.3 & 40.0 \\
\hline 0.5 & 0 & 6.3 & Agar & 0 & 6.7 & 6.7 \\
\hline 0.5 & 1.0 & 6.3 & Agar & 26.7 & 20.0 & 46.7 \\
\hline 0.5 & 2.0 & 6.3 & Agar & 13.3 & 40.0 & 53.3 \\
\hline
\end{tabular}

$z$ Shoots were induced from callus by culturing on the callus formation medium (1/2 MS medium contained KM8p vitamins, $0.1 \mathrm{mg} \cdot$ liter $^{-1} \mathrm{GA}_{3}$ ) for about one month and transferred to shoot formation medium (MS medium without plant growth regulators).

y 15 shoots were transplanted in each experiment.

Mutoh (1991) reported that the development of ad. ventitious root was inhibited by sucrose. In our study, adventitious roots developed most vigorously on the medium containing $2 \%$ sucrose.

When regenerated plantlets were transplanted to the pot and grown in a greenhouse (Fig. 2), the acclimatized plants flowered within 2 months after

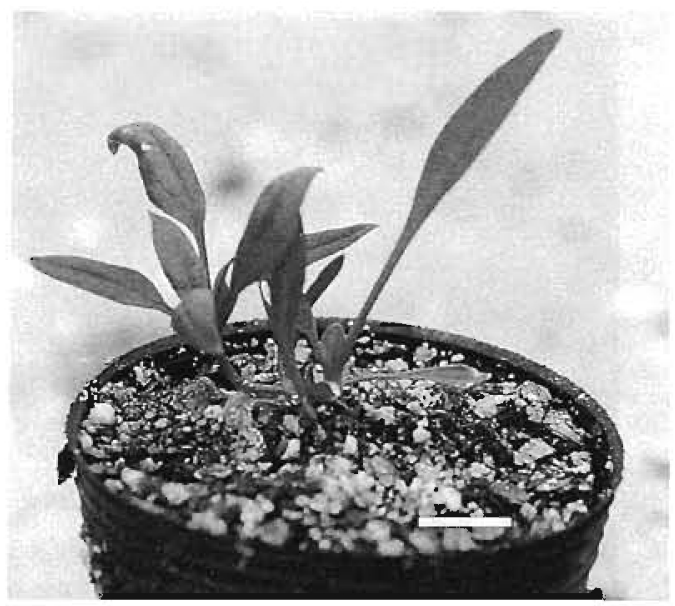

Fig. 2. A regenerated plant from a mesophyll protoplast-derived callus. $\quad B a r=1.0 \mathrm{~cm}$.

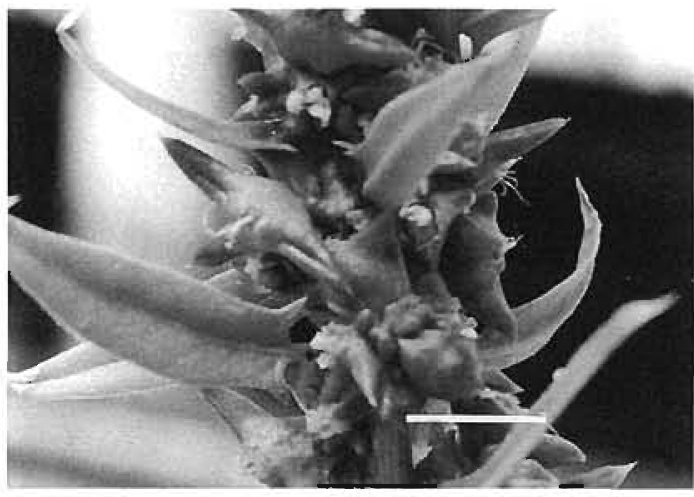

Fig. 3. Fruit formation on a monoecious regenerant. Bar $=0.5 \mathrm{~cm}$.

transplanting. Their floral characteristics revealed that they were dioecious male, dioecious female or monoecious. The monoecious plants produced many seeds by self-pollination (Fig. 3 ).

\section{Discussion}

In our previous study (Goto and Miyazaki, 1992), we used protoplast culture medium containing mannitol as an osmoticum. However, in this study, we found that glucose used for both carbon source and osmoticum was superior to mannitol. The same result was reported by Mii et al. (1991).

KM8p medium often used for protoplast culture contains much more kinds of vitamins and organic substances than the other media. We reported that 
frequencies of protoplast division and colony formation were much higher in the medium containing KM8p vitamins than MS vitamins (Goto and Miyazaki, 1992). Protoplasts were injured by KM8p organic acids when they were cultured on the medium containing $0.5 \mathrm{M}$ mannitol, whereas they were not in the medium containing $0.5 \mathrm{M}$ glucose. Furthermore, they divided more rapidly in the presence of KM8p organic acids than in the medium without them.

In spinach, shoot regeneration from the callus developed from a hypocotyl segment was achieved in the medium containing IAA and $\mathrm{GA}_{3}$ (Sasaki, 1989 ; Satoh et al., 1992). Xiao et al. (1993) reported that somatic embryos were obtained from the calli which were induced on solid media supplemented with IAA and $\mathrm{GA}_{3}$ and then subcultured on IAA containing media. In the present study, shoot regeneration was observed in the medium containing $1.0 \mathrm{mg} \cdot$ liter $^{-1} \mathrm{GA}_{3}$ and either 5.0-10.0 mg $\cdot$ liter $^{-1}$ IAA or $1.0-5.0 \mathrm{mg} \cdot$ liter $^{-1}$ IBA. These media were more effective for inducing shoot regeneration from the protoplast-derived calli than previous ones employed by us. Induction of shoot from the callus could be observed only in the media containing $\mathrm{GA}_{3}$ (Data was not shown). However, the rate of shoot regeneration was lower than that obtained in the other tissue culture studies (Sasaki, 1989; Al-Khayri et al., 1991 ; Satoh et al., 1992 ; Xiao et al., 1993 ; Okuse et al., 1994). Thus, it is necessary to develop a more effective medium for shoot regeneration from protoplast-derived calli.

Although the $\mathrm{pH}$ of medium is usually adjusted to $\mathrm{pH} 5-6$, adventitious root formation and subsequent root growth were more vigorous in the medium adjusted to $\mathrm{pH} 6.3$ than in $\mathrm{pH}$ 5.8. Spinach is very sensitive to soil acidity; it grows poorly in soils below pH 5.5 (Zimmerley, 1924). Seemingly, this character influences both the formation and development of adventitious roots.

Fujita et al. (1994) isolated spinach protoplasts and induced callus formation but they were unable to regenerate plantlets. In this study, an efficient procedure was developed by modifying the culture medium. This procedure could be applied to new methods, such as cell fusion and direct gene transfer in spinach breeding.

\section{Acknowledgment}

The authors would like to thank Dr. S. Misoo of Kobe University for his valuable advice and suggestions.

\section{Literature Cited}

Al-Khayri, J. M., F. H. Huang and T. E. Morelock. 1991. Regeneration of spinach from leaf callus. HortScience 26 : 913-914.

Fujita, S., S. Sugiyama, M. Endo, I. Inada and O. Yama. da. 1994. Studies on the protoplast culture of spinach and chard. J. Japan. Soc. Hort. Sci. 63 (Suppl. 1) : 228-229. (In Japanese).

Goto, T. and M. Miyazaki. 1992. Plant regeneration from mesophyll protoplasts of Spinacia oleracea $\mathrm{L}$. Plant Tissue Culture Lett. $9: 15-21$.

Kao, K. N. and M. R. Michayluk. 1975. Nutritional requirements for Vicia hajastana cells and protoplasts at a very low population density in liquid media. Planta (Berl.) 126:105-110.

Mii, M., Y.-M. Zou, T. Sugiyama, S. Yanagihara and M. lizuka. 1991. High-frequency callus formation from protoplasts of Vitis labruscana Bailey and $V$ itis thunbergii Sieb. et Zucc. by embedding gellan gum. Scientia Hort. 46 : 253-260.

Murashige, T. and F. Skoog. 1962. A revised medium for rapid growth and bioassays with tobacco tissue cultures. Physiol. Plant. 15 : 473-497.

Mutoh, M. 1991. Induction of embryogenesis from spinach. Bio Horti 5 : 24-25. (In Japanese).

Okuse, I., K. Saga and F. Komai. 1994. In vitro culture of roots in spinach. J. Japan. Soc. Hort. Sci. 63 (Suppl. 1) : 226-227. (In Japanese).

Sasaki, H. 1989. Callus and organ formation in tissue culture of spinach (Spinacia oleracea L.). J. Japan. Soc. Hort. Sci. 58: 149-153.

Satoh, T., T. Abe and T. Sasahara. 1992. Plant regeneration from hypocotyl-derived calli of spinach (Spinacia oleracea L.) and anatomical characteristics of regenerating calli. Plant Tissue Culture Lett. $9:$ 176-183. (In Japanese).

Xiao, Xing-Guo and M. Branchard. 1993. Embryog enesis and plant regeneration of spinach (Spinacia oleracea L.) from hypocotyl segments. Plant Cell Rep. $13: 69-71$.

Zimmerley, H. H. 1924. The acid tolerance range of spinach. Proc. Amer. Soc. Hort. Sci. 21 : 116-124. 
ホウレンソウプロトプラスト培養における培養効率の向上

後藤隆子·宮崎正則 ·舆 正和

（財）東洋食品研究所 666 川西市南花屋敷 4-23-2

\begin{abstract}
摘 要
ホウレンソウ葉肉由来プロトプラストからのより効 率的な植物体再生システムを培地中の有機物や生長調 節物質などの組み合わせを検討することで確立した。

プロトプラストの分裂率は KM8p ビタミン, 1.0 $\mathrm{mg} \cdot \mathrm{liter}^{-1} \mathrm{BA}, 1.0 \mathrm{mg} \cdot \mathrm{liter}^{-1}$ 2,4-D 抢よび $0.5 \%$ グル コースを含む $1 / 2 \mathrm{MS}$ 培地で最も高く, 浸透圧調節剈 としてマニトールよりグルコースを培地に加えた方が 分裂は著しく旺盛であった。また，炭素源としてスク ロースよりグルコースを加えた方が分裂率が高かった。 KM8p の有機酸を培地に添加すると, 浸透圧調節郕が マニトールの場合には分裂が阻害されたが，グルコー スであると反対にやや促進された，プロトプラスト由 来コロニーを KM8p ビタミン, $1.0 \mathrm{mg} \cdot \operatorname{liter}^{-1} \mathrm{GA}_{3}$, および濃度の異なる種々のオーキシンを含む MS 固体

いは 1.0-5.0 mg・liter ${ }^{-1}$ IBAを含む培地で多くのカル スが形成された．さらに形成されたカルスを生長調節 物質を含まないMS 固体培地へ移植すると，1.0-10.0 $\mathrm{mg} \cdot \mathrm{liter}^{-1}$ IAA あるいはIBA を含むカルス形成培地で 培盖されたカルスでシュート形成が観察された．それ らのシュートを0.5 mg·liter ${ }^{-1}$ IBA，2\%スクロースお よび $0.8 \%$ 寒天を含む MS 培地（pH 6.3）に移植する と多くのシュートから不定根が分化し，生長した．再 分化した植物体を順化後, 温室で育成したところ，そ れらの幾つかが開花し，正常な種子を生産した。

本研究で確立されたホウレンソウのプロトプラスト 培盖システムは, 細胞融合や遺伝子導入など新しい技 術を利用して育種を行う場合に有効であると考えられ る。
\end{abstract} 培地に移植したところ，1.0-10.0 mg·liter ${ }^{-1}$ IAA ある 